\title{
Economic and Environmental Assessment of the Use of Renewable Energies in Greenhouses: A Case Study in Crete-Greece
}

\author{
John Vourdoubas ${ }^{1}$ \\ ${ }^{1}$ Department of Natural resources and Environmental Engineering, Technological Educational Institute of Crete, \\ Greece \\ Correspondence: John Vourdoubas, Department of Natural resources and Environmental Engineering, \\ Technological Educational Institute of Crete, TEI of CRETE, 3 Romanou str., 73133, Chania, Crete, Greece. Tel: \\ 30-282-102-3070. E-mail: vourdoubas@chania.teicrete.gr
}

Received: June 21, 2015 Accepted: July 22, 2015 Online Published: September 15, 2015

doi:10.5539/jas.v7n10p48 URL: http://dx.doi.org/10.5539/jas.v7n10p48

\begin{abstract}
The use of various renewable energy resources in agricultural greenhouses for heat and power generation has been studied extensively and several applications already exist. Among renewable energy resources solar energy, geothermal energy and biomass have been more or less used mainly for heat production in them.

Currently economic and environmental considerations favour the replacement of fossil fuels with renewable energies for energy generation in greenhouses. The necessity of mitigation of greenhouse gases emissions and the decrease in the cost of energy generation from renewables make their use more attractive in various commercial applications including in agricultural greenhouses. In the case of Crete-Greece, cost analysis of the use of solid biomass and geothermal energy for direct heating and cooling greenhouses shows that these investments are very profitable and attractive. However, the use of geothermal heat pumps for heating and cooling them is not cost effective. Use of solar photovoltaic cells for power generation is not cost effective, particularly when electricity generation in greenhouses is subsidized by the government. The decrease of $\mathrm{CO}_{2}$ emissions due to the use of renewables in the greenhouses is considered as an additional benefit.
\end{abstract}

Keywords: agricultural greenhouses, biomass, geothermal energy, heat, heat pumps, power, renewable energy resources, solar energy

\section{Introduction}

The use of renewable energy sources in various applications results in many environmental benefits. The necessity to cope with climate changes restricts the use of fossil fuels and favours their replacement with renewable fuels. Recent technological advances in renewable energy technologies favour their use in heat and power generation, which in many cases is profitable without any financial support and subsidies from the governments.

Agricultural greenhouses use energy for covering their needs in:
a) Space heating
b) Space cooling
c) Lighting
d) Operation of various electric devices.

Among renewable energy resources, solar energy can be used for space heating and cooling, as well as for power generation. Solid biomass including agricultural and forest residues and byproducts can be used for space heating. Geothermal energy is due to the existing heat inside the earth since below the surface of the planet and in the way to the centre of the earth temperatures rise steadily. Geothermal energy can be used for heating greenhouses in two ways. A) From the hot water which is coming out from a water spring or is collected with underground pumping. B) Pumping the heat from the water or the soil in low depth where the temperature is slightly higher than the ambient with heat pumps. For cooling the greenhouse the heat pump absorbs the heat from inside the greenhouse and dissipates it in the soil or in the water in low depth. Geothermal energy can be used for space heating utilizing directly low or medium enthalpy geothermal fluids or for space heating and 
cooling with low enthalpy geothermal heat pumps.

Agricultural greenhouses need more energy for space heating in order to maintain indoor temperatures at 18-19 ${ }^{\circ} \mathrm{C}$ if needed and less energy for lighting and operation of various electric devices. The conventional fuels which they use include fuel oil, diesel oil and natural gas for space heating and grid electricity for their power needs. In some countries, including Greece, the government subsidies the electricity use in agriculture in order to support food production resulting in significantly lower electricity prices in greenhouses compared with the corresponding prices in households or in commercial enterprises.

\section{Use of Renewable Energy Sources in Agricultural Greenhouses}

Various renewable energy resources are used today for covering mainly the heating needs of agricultural greenhouses like solar energy, solid biomass and geothermal energy. Extensive research has been made and various experimental and demonstration systems for using photovoltaic cells, wind mills, biogas and geothermal heat pumps in them, already exist.

The availability of a renewable energy resource in a location affects its possible use in greenhouses. Presence of a geothermal spring, high solar irradiance or availability and low prices of solid biomass nearby the location of the greenhouses is a critical factor for their utilization. The abovementioned renewable energy technologies are currently mature, reliable and cost effective and particularly for solar PV cells their prices have decreased substantially the last few years. Renewable energy sources which can be used in greenhouses are presented in Table 1.

Table 1. Renewable energy sources which can be used for energy generation in greenhouses

\begin{tabular}{lllll}
\hline Renewable Energy & Generated Energy & Covering of energy needs & Investment cost & Operating cost \\
\hline Solar thermal & Thermal & Part & Medium & Very low \\
Solid biomass & Thermal & All & Medium & Medium - high \\
Direct geothermal fluids & Thermal & All & Low & Low \\
Geothermal heat pumps & Thermal & All & High & High \\
Solar PV & Electricity & All & Medium & Very low \\
\hline
\end{tabular}

It has been reported (Campiotti et al., 2012) that nowdays the proportion of renewable use in the total energy consumption in agricultural greenhouses in Europe is very low and there are not clear priorities and policies set in this area yet.

\section{Solar Thermal Energy}

Solar energy has been used for heating and cooling greenhouses. Passive solar systems in greenhouses have been reviewed (Santamouris et al., 1994). They have presented the results of 95 solar greenhouses from around the world representing the state of the art in this field. Another study (Sethi et al., 2008) evaluates some solar heating technologies in them. A passive solar greenhouse offering heat and cooling with an earth to air heat exchanger and buried pipes has been reported (Santamouris et al., 1994). A survey of thermal performances of a solar system has been studied (Santamouris et al., 1995). Solar energy used for heating of an agricultural greenhouse in Morocco has been proposed (Bargach et al., 2000).

In general solar thermal energy can be used for covering only part of the heating and cooling needs of a greenhouse. Depending on the local climate and the energy needs solar thermal energy can increase in the winter and decrease during the summer few degrees the indoor temperature of the greenhouse.

\section{Solid Biomass}

Various types of agricultural and forest byproducts and residues can be used for heat generation in greenhouses. A greenhouse cultivated with flowers and heated with solid biomass in Crete-Greece has been reported (Vourdoubas, 2015). Olive Kernel wood with a current cost 0.08 Euros $/ \mathrm{kg}$ is used as fuel and the heating system covers all the heating needs of the greenhouse maintaining an indoor temperature approx. at $19{ }^{\circ} \mathrm{C}$. The cost of heating depends on the price of biomass, the local climate and the type of the construction of the greenhouse.

\section{Direct Heating with Geothermal Fluids}

Direct heating of greenhouses with low enthalpy geothermal fluids with temperatures $40-80{ }^{\circ} \mathrm{C}$ has been 
reported (Adaro et al., 1999; Bakos et al., 1999) and various geothermal greenhouses operate to day all over the world. In the case that a geothermal spring in located nearby the greenhouse, a low cost heat source can be used and the greenhouse has a potential competitive advantage regarding its heating compared with other greenhouses. The cost of the heating system includes the cost of pumps and the tubes for transferring the geothermal fluid to the greenhouse as well as the cost of disposing the used geothermal fluid.

Geothermal fluids depending on their temperatures and flow rates can cover all the heating needs of agricultural greenhouses.

\section{Geothermal Heat Pumps}

Use of geothermal heat pumps for heating and cooling greenhouses consists of a rather expensive but effective method since they are very energy efficient electric devices (Ozgener et al., 2007).

They can cover all the heating and cooling needs of a greenhouse utilizing the low enthalpy ground heat obtaining high C.O.P. in the range of 3-4.

\section{Photovoltaic Cells}

Photovoltaic (PV) cells installed in a greenhouse can generate electricity covering all the power needs of it. Interconnected with the electric grid they can generate annually all the electricity that the greenhouse consumes zeroing its electricity payments and contributing in energy saving in it.

The decrease of PV cells cost during the recent years has made their use in various applications, including greenhouses, more attractive. However, existing policies in many countries regarding state subsidies in electricity cost for the agricultural sector reduces the attractiveness of PV cells.

\section{Economic Assessment of a Solid Biomass System for Space Heating in a Greenhouse}

Economic assessment of a heating system using solid biomass as a fuel in Crete-Greece has been made. It has been assumed that an existing greenhouse has a heating system utilizing fuel oil and it will replace it with a new one utilizing solid biomass (olive kernel wood). Since the price of solid biomass is cheaper than the price of fuel oil an economic benefit will result due to the change from a fossil fuel to a renewable fuel. An additional investment for the solid biomass heating system is required in the greenhouse. Data for the economic estimation of the solid biomass heating system are presented in Table 2.

Table 2. Data of economic analysis of a solid biomass heating system in a greenhouse

\begin{tabular}{ll}
\hline Area of the greenhouse & $1000 \mathrm{~m}^{2}$ \\
Annual heat consumption & $220000 \mathrm{KWH}$ \\
Peak heating load & $160000 \mathrm{KCAL} / \mathrm{H}$ \\
Power of Biomass boiler & $185.8 \mathrm{KW}$ \\
Unit cost of biomass boiler & $80 € / \mathrm{KW}$ \\
Cost of biomass heating system & $14864 €$ \\
Price of biomass & $0.08 € / \mathrm{kg}$ \\
Annual consumption of biomass & $66.87 \mathrm{tons}$ \\
Annual cost of biomass & $5350 €$ \\
Fuel oil needed to head the greenhouse & $26.75 \mathrm{tons} / \mathrm{year}$ \\
Cost of fuel oil & $40 € / \mathrm{ton}$ \\
Annual cost of fuel oil & $10700 €$ \\
Annual benefit due to change of the heating fuel & $5350 €$ \\
Period of operation & 15 years \\
Interest rate & $2 \%$ \\
\hline
\end{tabular}

Net present value of the investment in a new heating system as well as the payback period are presented in Figure 1. 


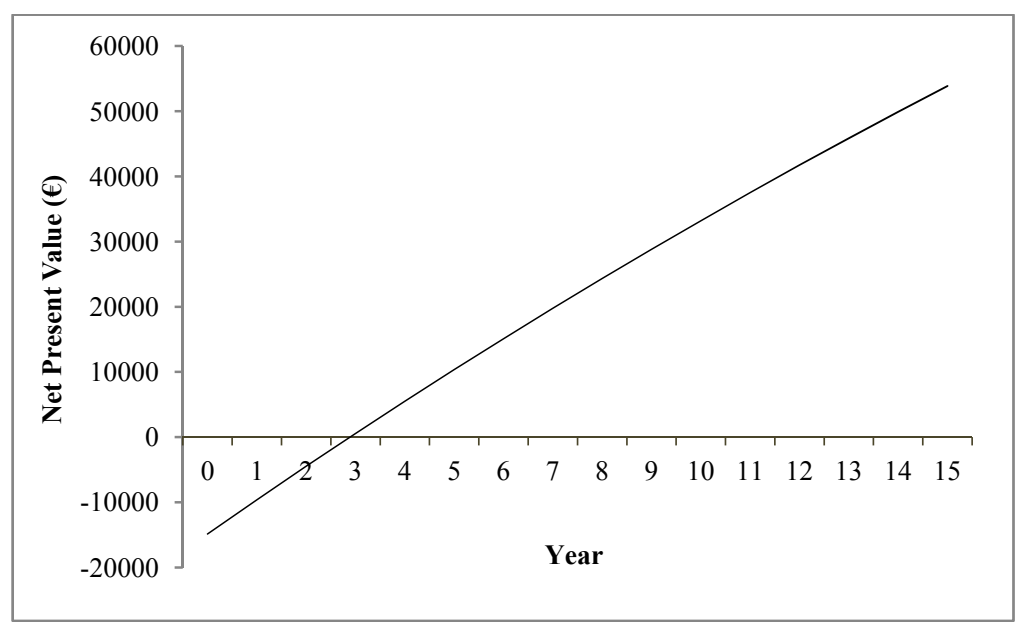

Figure 1. Net present value and payback period for an investment of a new solid biomass heating system in a greenhouse (Operating period: 15 years, interest rate: $2 \%$ )

It should be noted that the solid biomass heating system has higher maintenance cost compared with the heating system using fuel oil which has not been taken into account.

\section{Economic Assessment of a Photovoltaic System Generating Electricity in a Greenhouse}

Economic assessment of a grid interconnected photovoltaic system installed in a greenhouse located in Crete-Greece generating the electricity consumed annually by the greenhouse is made. In that case based on a net-metering system the annual net consumption of a grid electricity from the greenhouse will be zero. The economic benefit of this investment will be equal to the annual cost of grid electricity which will be paid without the installation of the PV system. Data for the economic analysis are presented in Table 3.

Table 3. Data of economic analysis of a grid interconnected PV system installed in a greenhouse generating annually the electricity used from it

\begin{tabular}{ll}
\hline Area of greenhouse & $1000 \mathrm{~m}^{2}$ \\
Annual consumption of electricity & $14000 \mathrm{KWH}$ \\
Price of grid electricity & $0.07 € / \mathrm{KWH}$ \\
Cost of electricity & $980 € /$ year \\
Annual electricity generation from PV & $1500 \mathrm{KWH} / \mathrm{KWp}$ \\
Nominal power of PV system & $9.33 \mathrm{KWp}$ \\
Unit cost of PV system & $1400 € / \mathrm{KWp}$ \\
Total investment cost of the PV system & $13062 €$ \\
Annual decrease of electricity generated from the PV system in 20 years period & $1 \%$ \\
Period of operation & 20 years \\
Interest rate & $2 \%$ \\
\hline
\end{tabular}

Net present value of the investment and payback period are presented in Figure 2. 


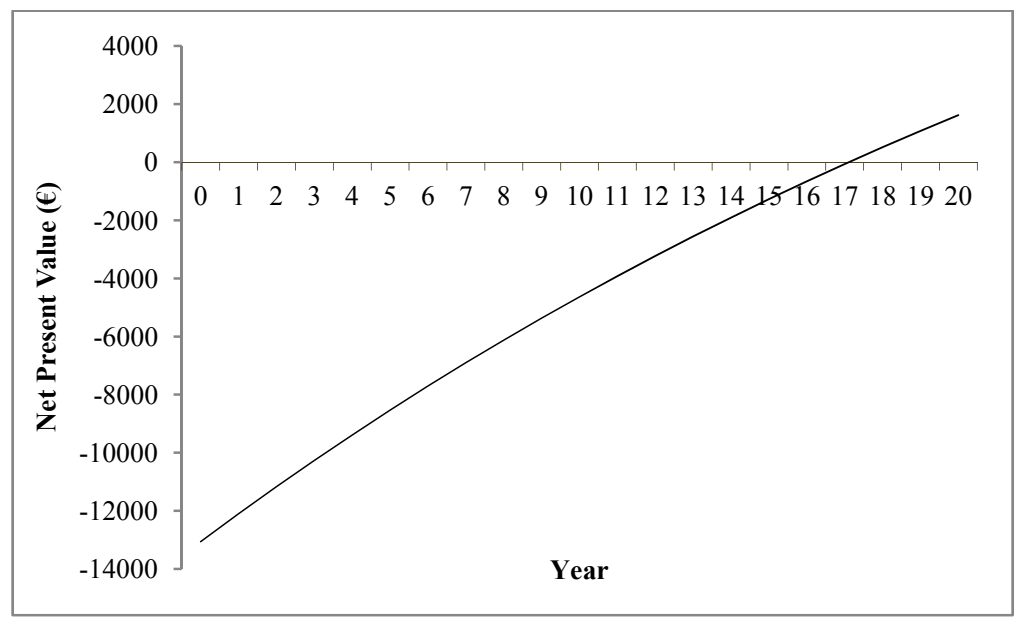

Figure 2. Net present value and payback period for a PV investment in a greenhouse (Operating period: 20 years, interest rate: $2 \%$, grid electricity cost: $0.07 € / \mathrm{KWH}$ )

Electricity cost in greenhouses in Greece is low due to governmental subsidies to agricultural sector. Net present value and payback period of the same investment is presented in figure 3 provided that grid electricity cost is $30 \%$ higher than the current cost $(0.091 € / \mathrm{KWH}$ instead of $0.07 € / \mathrm{KWH})$.

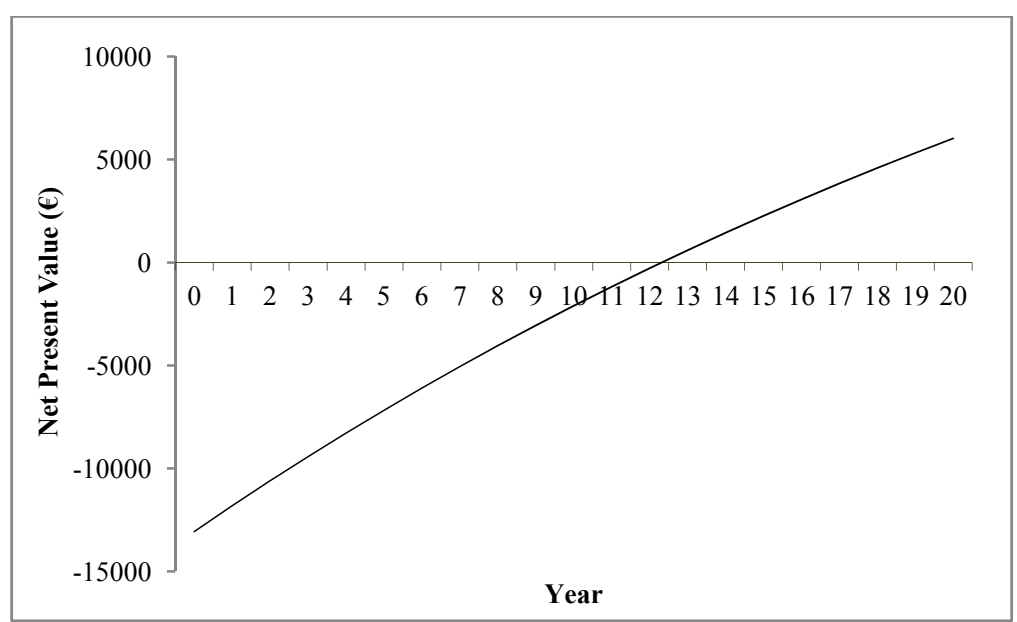

Figure 3. Net present value and payback period for a PV investment in a greenhouse (Operating period 20 years, interest rate $2 \%$, grid electricity cost $0.091 € / \mathrm{KWH})$

Comparing Figures 1 and 2 it can be seen that when grid electricity cost is higher the net present value is higher and the payback period shorter. Therefore, the governmental subsidies to grid electricity cost in agricultural sector in Greece discourage photovoltaic cell investments in greenhouses.

\section{Economic Assessment of a Low Enthalpy Geothermal Heat Pump for Space Heating in a Greenhouse}

Economic assessment of a heating system using a low enthalpy geothermal heat pump for space heating which will replace the conventional heating system with fuel oil has been made.

The heat pump can be used also for space cooling during summer. Heat pump is expensive equipment and utilizes electricity. However, it has high C.O.P and it is considered as a valuable energy saving device. The annual benefit of the greenhouse is the difference of the cost of the fuel oil used for space heating and the cost of the required electricity for the operation of the heat pump. Since electricity is subsidized in the agricultural sector in Greece, it favours the use of heat pumps which consume electricity. Data for the economic estimation of the geothermal heat pump are presented in Table 4. 
Table 4. Data for economic analysis of a greenhouse heating system with geothermal heat pump

\begin{tabular}{ll}
\hline Area of greenhouse & $1000 \mathrm{~m}^{2}$ \\
Annual heat consumption & $220000 \mathrm{KWH}$ \\
Peak heating load & $160000 \mathrm{KCAL} / \mathrm{H}$ \\
C.O.P. of heat pump & 3.5 \\
Nominal power of heat pump & $53.1 \mathrm{KW}$ \\
Unit cost of heat pump & $2300 € / \mathrm{KW}$ \\
Annual electricity consumption of the heat pump & $62857 \mathrm{KWH}$ \\
Electricity cost & $0.07 \mathrm{Euro} / \mathrm{KWH}$ \\
Annual cost of electricity consumed by the heat pump & $4400 €$ \\
Investment cost of heat pump & $122130 €$ \\
Annual consumption of fuel oil for heating & 26.75 tons \\
Cost of fuel oil & $40 € /$ ton \\
Annual cost of fuel oil & $10700 €$ \\
Benefit due to change of the heating system & $6300 € /$ year \\
Period of operation & 20 years \\
Interest rate & $2 \%$ \\
\hline
\end{tabular}

The benefit which results from the use of geothermal heat pump for space cooling is small and it has not been taken into account.

It should be noted that heat pump has been rated to cover the peak heating load of the greenhouse and this increases its size and its price.

Net present value and payback period for an investment of a geothermal heat pump for heating a greenhouse are presented in Figure 4.

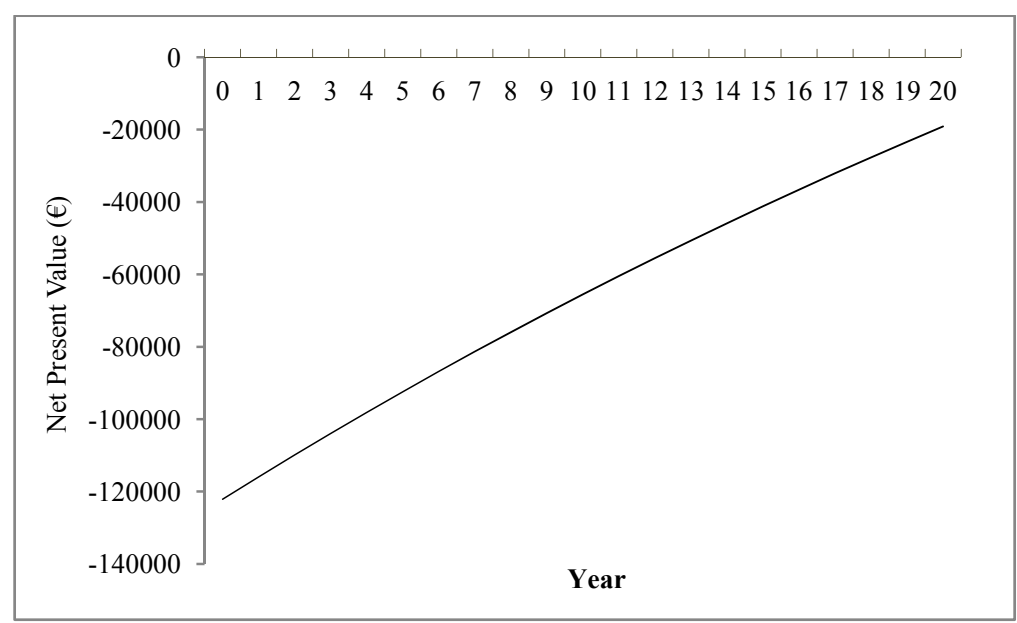

Figure 4. Net present value and payback period for an investment of a geothermal heat pump for heating a greenhouse (Operating period: 20 years, interest rate: $2 \%$ )

\section{Economic Assessment of a Greenhouse Directly Heated with Low Enthalpy Geothermal Fluid}

Economic assessment of a direct heating system of a greenhouse with low enthalpy geothermal fluid in Crete-Greece has been made. It has been assumed that a geothermal spring with hot water $50-60{ }^{\circ} \mathrm{C}$ is located nearby the greenhouse and the hot water is transferred to the greenhouse directly for heating. The fluid after its use is disposed in a nearby well. In that case the heating cost is estimated at $20 \%$ of the initial fuel cost 
(http://energy.gov/eere/geothermal/direct-use-geothermal-energy), and the economic benefit equals $80 \%$ of the cost of the initially used fuel oil.

Results for the economic analysis of heating greenhouses directly with geothermal fluids are presented in Table 5. The initial investment cost depends on the distance of the geothermal spring from the greenhouse, the temperature and the flow rate of the fluid.

Table 5. Data of economic analysis of direct heating of a greenhouse with low enthalpy geothermal fluids

\begin{tabular}{ll}
\hline Area of greenhouse & $1000 \mathrm{~m}^{2}$ \\
Annual heat consumption & $220000 \mathrm{KWH}$ \\
Peak heating load & $160000 \mathrm{KCAL} / \mathrm{H}$ \\
Annual consumption of fuel oil for heating & 26.75 tons \\
Cost of fuel oil & $40 € /$ ton \\
Annual cost of fuel oil & $10700 €$ \\
Annual benefit due to geothermal system & $8560 €$ \\
Investment cost of the geothermal heating system (includes insulated pipes, pumps, disposal system etc) & $12500 €$ \\
Operating period & 20 years \\
Interest rate & $2 \%$ \\
\hline
\end{tabular}

Direct heating with geothermal fluids is possible only in the case of presence of geothermal springs nearby the location of the greenhouses.

Net present value and payback period for the investment of direct greenhouse heating with geothermal fluids are presented in Figure 5.

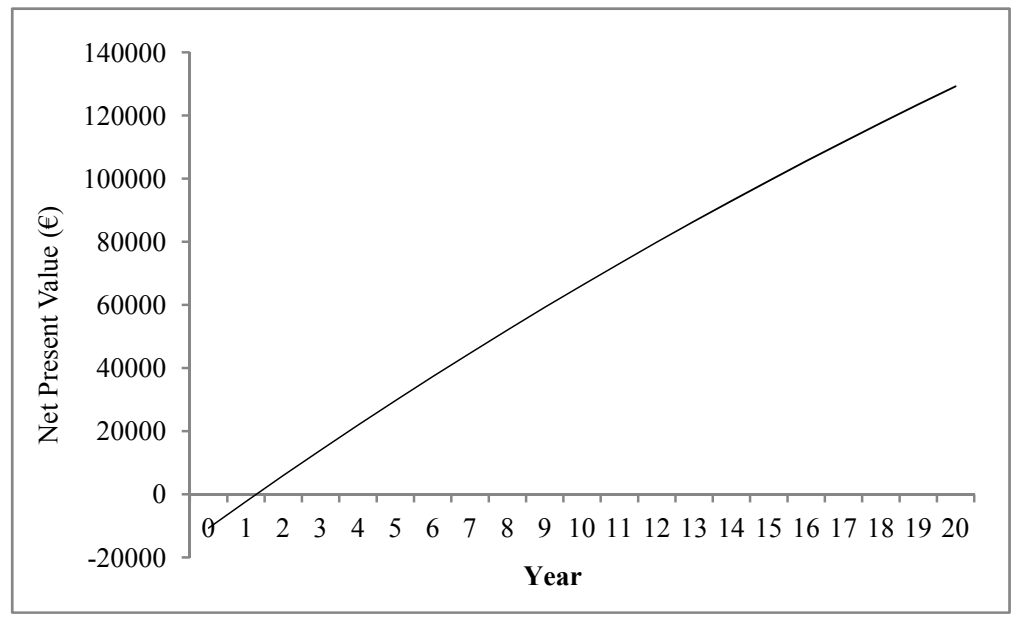

Figure 5. Net present value and payback period for the investment of direct greenhouse heating with geothermal fluids (Operating period: 20 years, interest rate: $2 \%$ )

\section{Profitability Analysis of Energy Generation with Various Renewable Energy Systems in Agricultural Greenhouses}

Results of the abovementioned applications of renewable energy systems in agricultural greenhouses in Crete-Greece are presented in Table 6. 
Table 6. Profitability analysis data of various applications of renewable energies in greenhouses in Crete-Greece

\begin{tabular}{lllll}
\hline Type of renewable energy & Energy generated & $\begin{array}{l}\text { Operating period } \\
(\text { years })\end{array}$ & $\begin{array}{l}\text { Initial investment } \\
(€)\end{array}$ & $\begin{array}{l}\text { Payback period } \\
(\text { years })\end{array}$ \\
\hline Solar PV & Electricity & 20 & 13062 & $\begin{array}{l}16.98 \\
12.30^{*} \\
6 V\end{array}$ \\
Solid biomass & Heat & 15 & 14864 & 2.95 \\
Direct heating with geothermal fluid & Heat & 20 & 12500 & 1.25 \\
Geothermal heat pumps & Heat (and cooling) & 20 & 122130 & 129268 \\
\hline
\end{tabular}

Note. ${ }^{*}$ In the case of $30 \%$ higher than current electricity prices.

Among the three abovementioned heating methods in greenhouses in Crete the most profitable is direct heating with geothermal fluids. Solid biomass use is also attractive provided that solid biomass is available in the presumed cost. Heating with geothermal heat pumps is not profitable although the subsidies in the electricity prices favour its use. However, heat pump cost can be reduced assuming that it will cover only the base heat load in the greenhouse and not the peak load.

In such a case the attractiveness of this technology will be improved. PV cells for electricity generation are not attractive with the current electricity prices in greenhouses which are subsidized in Greece. Increase of electricity prices in the agricultural sector will improve the attractiveness of grid interconnected solar cells installed in greenhouses with net-metering system.

\section{Environmental Benefits due to the Use of Renewable Energy Systems}

Use of the abovementioned renewable energy systems for heat and power generation in the greenhouses will result in reduction of greenhouses gases emitted due to energy use in them. The reductions are estimated as the difference of the emissions due to fossil fuels use minus the emissions due to renewable energy use. In the case of using PV cells, direct heating with geothermal fluids and heating with solid biomass the $\mathrm{CO}_{2}$ emissions are zero. In the case of using the geothermal heat pump the emissions are estimated from the consumption of grid electricity for the operation of the heat pump.

It is assumed that for grid electricity use the emission coefficient is $0.989 \mathrm{~kg}$ of $\mathrm{CO}_{2}$ per $\mathrm{KWH}$ and for fuel oil use $3.2 \mathrm{~kg}$ of $\mathrm{CO}_{2}$ per $\mathrm{kg}$ of fuel oil. Environmental benefits due to the use of renewable energy sources in agricultural greenhouses are presented in Table 7.

Table 7. Environmental benefits due to renewable energy use in greenhouses

\begin{tabular}{|c|c|c|c|c|c|}
\hline $\begin{array}{l}\text { Type of renewable } \\
\text { energy used }\end{array}$ & $\begin{array}{l}\text { Energy used } \\
\text { initially }\end{array}$ & Energy generated & $\begin{array}{l}\text { Initial } \mathrm{CO}_{2} \\
\text { emissions } \\
\text { (tons/year } * 10^{3} \mathrm{~m}^{2} \text { ) }\end{array}$ & $\begin{array}{l}\mathrm{CO}_{2} \text { emissions due } \\
\text { to renewable } \\
\text { (tons/year } * 10^{3} \mathrm{~m}^{2} \text { ) }\end{array}$ & $\begin{array}{l}\text { Reduction of } \mathrm{CO}_{2} \\
\text { emissions } \\
\text { (tons/year* } 10^{3} \mathrm{~m}^{2} \text { ) }\end{array}$ \\
\hline Solar PV & Grid electricity & Electricity & 13.85 & 0 & 13.85 \\
\hline Solid biomass & Fuel oil & Heat & 85.60 & 0 & 85.60 \\
\hline $\begin{array}{l}\text { Direct heating with } \\
\text { geothermal fluid }\end{array}$ & Fuel oil & Heat & 85.60 & 0 & 85.60 \\
\hline Geothermal heat pumps & Fuel oil & Heat (and cooling) & 85.60 & 62.17 & 23.43 \\
\hline
\end{tabular}

\section{Conclusions}

Renewable energy sources can replace fossil fuels for covering all the energy needs of agricultural greenhouses. Among them solar energy, geothermal energy and biomass can be used for generation of heat, cooling and electricity in them. Profitability analysis has shown that heating of greenhouses in Crete - Greece either directly with low enthalpy geothermal fluids or with solid biomass is profitable and very attractive compared with heating them with fuel oil.

However, their heating with low enthalpy geothermal heat pumps is not cost effective although the price of electricity in the agricultural sector in Greece is low due to state subsidies. Use of PV cells interconnected with 
the electrical grid for covering the electricity needs of the greenhouses is not either cost effective due to state subsidies in the price of electricity. However, in the case that the price of electricity will be $30 \%$ higher than the current then the use of PV cells in the greenhouses is becoming more attractive. Regarding environmental benefits due to the use of renewable, the higher reductions in $\mathrm{CO}_{2}$ emissions are obtained with the use of solid biomass and with direct heating with geothermal fluids. Lower environmental benefits are obtained with the use of PV cells and geothermal heat pumps in the greenhouses. Therefore, the use of solid biomass and geothermal fluids for direct heating in the greenhouses has important economic and environmental benefits and it should be promoted with various policies.

\section{References}

Adaro, J. A., Galimberti, P. D., Lema, A. I., Fasulo, A., \& Barral, J. R. (1999). Geothermal contribution to greenhouse heating. Applied Energy, 64, 241-249. http://dx.doi.org/10.1016/S0306-2619(99)00049-5

Bakos, G. C., Fidanidis, D., \& Tsagas, N. F. (1999). Greenhouse heating using geothermal energy. Geothermics, 28, 759-765. http://dx.doi.org/10.1016/S0375-6505(99)00041-3

Bargach, M. N., Tadili, R., Dahman, A. S., \& Boukallouch, M. (2002). Survey of thermal performances of a solar system used for the heating of agricultural greenhouses in Morocco. Renewable Energy, 20, 415-433. http://dx.doi.org/10.1016/S0960-1481(99)00118-4

Chou, S. K., Chua, K. J., Ho, J. C., \& Ooi, C. L. (2004). On the study of an energy efficient greenhouse for heating, cooling and dehumidification applications. Applied Energy, 77, 355-373. http://dx.doi.org/10.1016/S0306-2619(03)00157-0

Esen, M., \& Yuksel, T. (2013). Experimental evaluation of using various renewable energy sources for heating a greenhouse. Energy and Buildings, 65, 340-351. http://dx.doi.org/10.1016/j.enbuild.2013.06.018

Ghosal, M. K., \& Tiwari, G. N. (2004). Mathematical modeling for greenhouse heating by using thermal curtain and geothermal energy. Solar Energy, 76, 603-613. http://dx.doi.org/10.1016/j.solener.2003.12.004

Jaffrin, A., Bentounes, N., Joan, A. M., \& Makhlouf, S. (2003). Landfill biogas for heating greenhouses and providing Carbon Dioxide supplement for plant growth. Biosystems Engineering, 86, 113-123. http://dx.doi.org/10.1016/S1537-5110(03)00110-7

Kurklu, A. (1998). Energy storage applications in greenhouses by means of phase change materials: a review. Renewable energy, 13, 89-103. http://dx.doi.org/10.1016/S0960-1481(97)83337-X

Nayak, S., \& Tiwari, G. N. (2008). Energy and energy analysis of photovoltaic/thermal integrated with a solar greenhouse. Energy and Buildings, 40, 2015-2021. http://dx.doi.org/10.1016/j.enbuild.2008.05.007

Ozgener, O., \& Hepbaslib, A. (2007). A parametrical study on the energetic and exergetic assessment of a solar-assisted vertical ground-source heat pump system used for heating a greenhouse. Building and Environment, 42, 11-24. http://dx.doi.org/10.1016/j.buildenv.2005.07.003

Santamouris, M., Argiriou, A., \& Vallindras, M. (1994). Design and operation of a low energy consumption passive solar agricultural greenhouse. Solar Energy, 52, 371-378. http://dx.doi.org/10.1016/0038-092X(94)90114-H

Santamouris, M., Balaras, C. A., Dascalaki, E., \& Vallindras, M. (1994). Passive solar agricultural greenhouse: A worldwide classification and evaluation of technologies and systems used for heating purposes. Solar Energy, 53, 411-426. http://dx.doi.org/10.1016/0038-092X(94)90056-6

Santamouris, M., Mihalakopoulou, G., Balaras, C. A., Argiriou, A., Asimakopoulos, D., \& Vallindras, M. (1995). Use of buried pipes for energy conservation in cooling of agricultural greenhouse. Solar Energy, 55, 111-124. http://dx.doi.org/10.1016/0038-092X(95)00028-P

Sethi, V. P., \& Sharma, S. K. (2008). Survey and evaluation of heating technologies for worldwide agricultural greenhouse applications. Solar Energy, 82, 832-859. http://dx.doi.org/10.1016/j.solener.2008.02.010

Vourdoubas, J. (1999). Heating greenhouses in Crete using Biomass: The case of olive-Kernel wood. In the conference Energy and agriculture towards the third millennium, Athens, Greece.

Vourdoubas, J. (2004). Comparison of greenhouse heating with geothermal energy, biomass and solar energy. In the conference Geothermal energy applications in agriculture, Athens, Greece.

Vourdoubas, J. (2009). Possibilities of zeroing $\mathrm{CO}_{2}$ emissions due to energy use in greenhouses in Crete. Journal of Agriculture and Cattle Breeding, 7, 66-73. 
Vourdoubas, J. (2015). Overview of heating greenhouses with renewable energy sources: A case study in Crete-Greece. Journal of Agriculture and Environmental Sciences, 4(1), in press.

Yildiz, A., Ozgener, O., \& Ozgener, L. (2001). Exergetic performance assessment of solar Photovoltaic cell assisted earth to air heat exchanger system for solar greenhouse cooling. Energy and Building, 43, 3154-3160. http://dx.doi.org/10.1016/j.enbuild.2011.08.013

\section{Copyrights}

Copyright for this article is retained by the author(s), with first publication rights granted to the journal.

This is an open-access article distributed under the terms and conditions of the Creative Commons Attribution license (http://creativecommons.org/licenses/by/3.0/). 